\title{
ASSESSMENT ON NUTRIENT LEVELS IN THE AERIAL BIOMASS OF IRRIGATED GUAVA IN SÃO FRANCISCO VALLEY, BRAZIL ${ }^{1}$
}

\author{
JOSELANNE LUIZA TRAJANO MAIA², LUIS HENRIQUE BASSOI ${ }^{3}$, DAVI JOSÉ SILVA ${ }^{3}$, MARIA AUXILIADORA \\ COELHO DE LIMA ${ }^{3}$, JOSTON SIMÃO DE ASSIS ${ }^{3}$, PATRICIA LÍGIA DANTAS DE MORAIS ${ }^{4}$
}

ABSTRACT- In perennial crops, fertilizers are applied to restore the amount of nutrient removed from the plant by harvesting. Nevertheless, the immobilized nutrient inside the whole plant should be considered. Based on it, the nutrient concentrations in the guava leaf and fruit and the nutrient contents removed by fruits and post-harvest pruning were evaluated in an irrigated orchard, in Petrolina, State of Pernambuco, Brazil. The greatest contents removed by fruits were $\mathrm{N}$ and $\mathrm{K}$ among the macronutrients, while Fe, $\mathrm{Zn}$ and $\mathrm{Mn}$ presented higher levels among the micronutrients. More than $60 \%$ of the total content of N, P, K, Mg, Fe, and B removed by pruning were immobilized in the leaf and non-marketable fruit.

Index terms: Psidium guajava, mineral nutrition, foliar analysis, fruit analysis.

\section{LEVANTAMENTO DOS NÍVEIS DE NUTRIENTES NA PARTE AÉREA DA GOIABEIRA IRRIGADA NO VALE DO SÃO FRANCISCO}

RESUMO- A aplicação de fertilizantes em culturas perenes baseia-se na reposição das quantidades de nutrientes removidas pelos frutos, mas a imobilização de nutrientes deve ser também considerada. Assim, foram determinadas as concentrações de nutrientes nas folhas e nos frutos da goiabeira cv.Paluma, irrigada, em Petrolina-PE, bem como as quantidades de nutrientes removidas pelos frutos e pela poda de frutificação do ciclo seguinte. Entre os macronutrientes, o $\mathrm{N}$ e o K foram os mais removidos pelos frutos, enquanto o $\mathrm{Fe}$, o $\mathrm{Zn}$ e $\mathrm{Mn}$ apresentaram maiores valores entre os micronutrientes. No mínimo, $60 \%$ das quantidades totais de N,P,K,Fe e B removidas pela poda estavam imobilizadas na folha e no fruto não-comerciável.

Termos para indexação: Psidium guajava, nutrição mineral, análise foliar, análise do fruto.

A great $\mathrm{N}$ and $\mathrm{K}$ needs in relation to $\mathrm{P}$ by the guava crop has been reported (Brasil Sobrinho et al., 1961; Khanduja \& Garg, 1980; Medina, 1988; Queiroz et al.; 1986), as well as a higher leaf nutrient concentrations in flowering than in fruit set time (Natale, 1993) and fruit ripening (Chadha et al., 1973). N, P, and K concentrations are higher in the new leaves, but decrease along the growing season, while $\mathrm{Ca}$ and $\mathrm{Mg}$ have an opposite behavior (Rodriguez, 1967; Chadha et al., 1973). Nevertheless, none of these studies were carried out for the São Francisco Valley conditions, in Northeastern Brazil. As the nutrient levels of an irrigated guava crop in this site have not been reported yet, this assessment presents an evaluation of nutrient concentration in leaves and fruits throughout one growing season, and the amount of nutrients removed by fruit harvesting and post-harvest pruning.

The experiment was carried out at Embrapa Tropical SemiArid, Petrolina, State of Pernambuco, Brazil (latitude $09^{\circ} 08^{\prime} 12^{\prime \prime} \mathrm{S}$, longitude 40 $19{ }^{\prime} 2$ " W, altitude 365,5 m), in a Yellow Red Latosol. Soil chemical characteristics, determined following the procedures described by Embrapa (1997) were, respectively, in the 0-0.2 and
0.2-0.4 m depths: low pH (5.8 and 5.0), low levels of $\mathrm{Ca}$ (1.3 and 0.7 $\left.\mathrm{cmol}_{\mathrm{c}} \mathrm{dm}^{-3}\right), \mathrm{Mg}\left(0.6\right.$ and $\left.0.6 \mathrm{cmol}_{\mathrm{c}} \mathrm{dm}^{-3}\right)$, and $\mathrm{K}\left(0.9\right.$ and $0.9 \mathrm{cmol}_{\mathrm{c}}$ $\left.\mathrm{dm}^{-3}\right)$, low exchangeable $\mathrm{Al}\left(0.1\right.$ and $\left.0.2 \mathrm{cmol}_{\mathrm{c}} \mathrm{dm}^{-3}\right)$, and low organic matter content ( 7.9 and $\left.5.2 \mathrm{~g} \mathrm{dm}^{-3}\right)$; the electrical conductivity (1.7 and $\left.0.6 \mathrm{dS} \mathrm{m}^{-1}\right)$ was a little high in the upper soil layer, while the $P$ content (46 and $8 \mathrm{mg} \mathrm{dm}^{-3}$ ) was also high due to the localized fertilizer application. Besides the desirable cation exchange capacity (5.0 and $5.0 \mathrm{cmol}_{c} \mathrm{dm}^{-3}$ ), the base saturation was low (57 and 44\%) as a consequence of the $\mathrm{H}^{+}+\mathrm{Al}^{+3}$ content (potential acidity of 2.1 and $2.8 \mathrm{cmol}_{\mathrm{c}} \mathrm{dm}^{-3}$ ) in both soil depths analyzed.

The guava orchard, cv. Paluma, was planted on March 1999 in a spacing grid of $5 \times 6 \mathrm{~m}$, and has been irrigated by micro sprinklers. The growing season analysis began at June $7^{\text {th }} 2001$ (pruning date), two years and three months after planting. Fertilizers were broadcasted under the canopy and among 20 to $40 \mathrm{~cm}$ from the trunk. Before pruning, it was applied $20 \mathrm{~L}$ of manure, $100 \mathrm{~g}$ of lime, $135 \mathrm{~g}$ of urea $(60 \mathrm{~g}$ of $\mathrm{N}), 75 \mathrm{~g}$ of potassium sulphate $\left(36 \mathrm{~g} \mathrm{~K}_{2} \mathrm{O}\right), 190 \mathrm{~g}$ of triple super phosphate $\left(80 \mathrm{~g} \mathrm{P}_{2} \mathrm{O}_{5}\right)$, and $50 \mathrm{~g}$ of FTE BR $12 ; 180 \mathrm{~g}$ of urea $(81 \mathrm{~g} \mathrm{~N})$ and $30 \mathrm{~g}$ of potassium sulfate $\left(15 \mathrm{~g} \mathrm{~K}_{2} \mathrm{O}\right)$ at 88 days after pruning (dap); $90 \mathrm{~g}$ of urea (40

(Paper 079-06). Received in : 05-06-2006. Accepted for publication at 28-03-2007.

2 CNPq fellow, Embrapa Tropical Semi-Arid, P.O. Box 23, 56302-970, Petrolina - PE, Brazil. Email: 1tmaia@uol.com.br

Researcher, Embrapa Tropical Semi-Arid, P.O. Box 23, 56302-970, Petrolina - PE, Brazil. Email: 1hbassoi@cpatsa.embrapa.br, davi@cpatsa.embrapa.br, maclima@cpatsa.embrapa.br, joston@cpatsa.embrapa.br.

${ }^{4}$ FAPERN/CNPq fellow, UFERSA, Dept of Phytopathology, P.O. Box 37, 59625-900, Mossoró - RN, Brazil. E.mail: plmorais@ufersa.edu.br 
$\mathrm{g} \mathrm{N})$ and $45 \mathrm{~g}$ of potassium sulfate $\left(22 \mathrm{~g} \mathrm{~K}_{2} \mathrm{O}\right)$ at $134 \mathrm{dap}$; and 40 $\mathrm{g}$ of urea $(18 \mathrm{~g} \mathrm{~N})$ and $60 \mathrm{~g}$ of potassium sulfate $\left(28 \mathrm{~g} \mathrm{~K}_{2} \mathrm{O}\right)$ per plant at 168 dap. The rates were determined following the soil chemical analyses and the fertilizer doses recommended by Gonzaga Neto et al. (1998), which range from 100 to $250 \mathrm{~g}$ of N; 40 to $100 \mathrm{~g}$ of $\mathrm{P}_{2} \mathrm{O}_{5}$, and 0 to $210 \mathrm{~g}$ of $\mathrm{K}_{2} \mathrm{O}$, based on soil fertility.

Twenty plants were targeted, and the canopy of each one was divided in quadrants, where the third pair of leaves, from the end of twigs with fruits and no injuries, were collected (Natale, 1993). For each sampling time, leaves from all trees composed only one sample, and four measurements of nutrient concentration were made in each one. The bi-weekly sampling was performed from flowering (61 dap) to fruit harvesting (187 dap). Fruits from the targeted trees were sampled from 82 to 187 dap for nutrient concentration analyses, and all fruits from each sampling time composed only one sample. In the harvesting period, the fruit number and weight per plant were determined, and after this period in December 2001, the guava orchard passed through a 112 days resting time (with no irrigation, fertilizing or other cropping practices). In the beginning of the next growing season, on April $15^{\text {th }} 2002$ (pruning date), the leaves, non-marketable fruits, thicker twigs (diameter $>1 \mathrm{~cm}$ ) and thinner twigs (diameter $\leq 1$ $\mathrm{cm}$ ) were collected from two plants to determine the nutrients removed by pruning. All leaves, fruits and other aerial parts were dried in a $65^{\circ} \mathrm{C}$ oven, weighted, grounded, and macro and micronutrient concentrations were determined following the procedures described by Malavolta et al. (1997).

The phenological stage (P) lengths were: P1 (bud break, vegetative growth and flowering): 0 to 63 dap; P2 (vegetative growth, end of flowering, physiological fruit drop, and beginning of fruit growing): 64 to 109 dap; P3 (fruit growing): 110 to 172 dap; P4 (ripening and fruit harvesting): 173 a 200 dap. The beginning of flowering was at 39 dap, and at 63 dap $50 \%$ of all plants were bloomed. This was the criterion to define the end of P1 and the beginning of P2 phenological stage. Fruit drop, a plant physiological process, occurred from 78 to 109 dap (P2), and fruit harvesting, from 153 to $200 \mathrm{dap}$, as consequence of non-uniformity on guava flowering.

The leaf N, K, and Ca concentrations were the highest, followed by the $\mathrm{S}, \mathrm{Mg}$, and $\mathrm{P}$ levels (Table 1). The leaf $\mathrm{N}$ concentration in $\mathrm{P} 1$ was higher than those obtained in other sampling times. In the beginning of $\mathrm{P} 2$, the $\mathrm{N}$ value decreased probably as a consequence of the intensive flowering, and remained without great changes until P3. As fruit development occurred, the $\mathrm{N}$ concentration presented a small decrease and remained practically with no variations until $\mathrm{P} 4$. The leaf $\mathrm{K}$ concentration was higher in the beginning of $\mathrm{P} 2$, but decreased until P3, when presented small changes until P4. The leaf $\mathrm{Ca}$ concentration had small changes in P1 and P2, but increased in P3 and remained with small variations in P4. In the last leaf sampling (P4), lower $\mathrm{N}$ and $\mathrm{K}$ concentrations were observed. These nutrients presented small changes probably due to the fertilizer split application. Nutrients with high mobility inside the plant tissues as $\mathrm{N}$ and $\mathrm{K}$ present a tendency of lower leaf concentration at the end of the growing season, due to nutrient translocation to the fruit, while the low mobility nutrients as $\mathrm{Ca}$ has the opposite (Malavolta et al., 1997). The leaf Mg concentration had small variations until the end of $\mathrm{P} 3$, when presented a peak followed by a decreasing in $\mathrm{P} 4$. The leaf $\mathrm{P}$ and $\mathrm{S}$ concentrations had small variations over all phenological stages. Both $\mathrm{Mg}$ and $\mathrm{P}$ have high mobility while $\mathrm{S}$ has low mobility in the phloem (Malavolta et al., 1997). Hence, it was expected the $\mathrm{Mg}$ and $\mathrm{P}$ decreasing and the $\mathrm{S}$ increasing at the end of the season, but they were not observed. A similar $\mathrm{Mg}$ behavior in mango leaf was described by Chadha et al. (1980).

The leaf composition depends upon several factors, as leaf age, phenological stage, twig position, leaf position in the twig, cultural practices, disease and plague presence, and environmental effects (Medina, 1988; Natale, 1997a). The leaf $\mathrm{P}$ and $\mathrm{Ca}$ concentrations from $\mathrm{P} 1$ are within the desirable range in the flowering time, although $\mathrm{N}, \mathrm{K}$ and $\mathrm{S}$ concentrations were higher and the $\mathrm{Mg}$ was lower than the levels $\left(\mathrm{g} \mathrm{kg}^{-1}\right)$ recommended by Natale (1997a), i.e., 20-23 for N, 14-17 for K, 2.5-3.5 for S, and 3.4-4 for $\mathrm{Mg}$. The leaf $\mathrm{N}$ concentration was higher than the ranges reported by Brasil Sobrinho et al. (1961) (4.6-16.8 $\left.\mathrm{g} \mathrm{kg}^{-1}\right)$, Ogata et al. (1979) (12.4 $\left.\mathrm{g} \mathrm{kg}^{-1}\right)$, Khanduja \& Garg (1980) (16.3-19.6 g kg1), and Raij et al. (1997) (13-16 $\left.\mathrm{g} \mathrm{kg}^{-1}\right)$, and lower than that reported by Malavolta et al. (1997) $\left(30 \mathrm{~g} \mathrm{~kg}^{-1}\right)$. The leaf $P$ concentration was in accordance with the level range determined by Raij et al. (1997) (1.4-1.6 $\left.\mathrm{g} \mathrm{kg}^{-1}\right)$, but it was higher than that described by Ogata et al. (1979) $\left(1.2 \mathrm{~g} \mathrm{~kg}^{-1}\right)$, and lower than the ranges determined by Khanduja \& Garg (1980) (1.8-2.4 $\left.\mathrm{g} \mathrm{kg}^{-1}\right)$ and Malavolta et al. (1997) $\left(3 \mathrm{~g} \mathrm{~kg}^{-1}\right)$. The leaf $\mathrm{K}$ concentration was higher than those reported by Rodriguez (1967) (15.4 $\left.\mathrm{g} \mathrm{kg}^{-1}\right)$, Ogata et al. (1979) $\left(8.9 \mathrm{~g} \mathrm{~kg}^{-1}\right)$ and Raij et al. (1997) (13-16 $\left.\mathrm{g} \mathrm{kg}^{-1}\right)$; lower than that described by Malavolta et al. (1997) $\left(30 \mathrm{~g} \mathrm{~kg}^{-1}\right)$, but it was within the range of Brasil Sobrinho et al. (1961) (2.2$\left.19.4 \mathrm{~g} \mathrm{~kg}^{-1}\right)$. Leaf $\mathrm{Ca}$ content was in accordance with Brasil Sobrinho et al. (1961) (3.3-9 $\mathrm{g} \mathrm{kg}^{-1}$ ) and Khanduja \& Garg (1980) (6.7-8.3 $\mathrm{g} \mathrm{kg}^{-1}$ ) until the beginning of P3, but was lower than the one according Malavolta et al. (1997) (13 $\left.\mathrm{g} \mathrm{kg}^{-1}\right)$ until the beginning of $\mathrm{P} 4$. The leaf $\mathrm{Mg}$ concentration reached the values described by Malavolta et al. (1997) $\left(3 \mathrm{~g} \mathrm{~kg}^{-1}\right)$ only in P3, but they were, respectively, higher and lower than those reported by Ogata et al. (1979) (2.2 $\left.\mathrm{g} \mathrm{kg}^{-1}\right)$ and Khanduja \& Garg (1980) (5.2-6.5 $\left.\mathrm{g} \mathrm{kg}^{-1}\right)$.

$\mathrm{Mn}$ and $\mathrm{Fe}$ presented the higher leaf micronutrient concentrations in guava tree, followed by $\mathrm{B}, \mathrm{Zn}$ and $\mathrm{Cu}$ (Table 1). Initially, the leaf $\mathrm{Mn}$ concentration showed small variations, but it increased in P3, followed by a smooth decrease in P4. The leaf Fe concentration presented a small peak in P2, followed by small variations in part of $\mathrm{P} 3$, and then an increase until the beginning of $\mathrm{P} 4$, and a decrease at harvest time. The $\mathrm{Cu}$ concentrations presented small variations until 131 dap, but afterwards it showed a sharp increase in P3 and P4, as a consequence of the application of $\mathrm{Cu}$ compounded chemical at 132 dap for disease control. The leaf B concentration had an increase along the guava growing season. In the flowering time (P1), leaf $\mathrm{Zn}$ concentration was higher than in other phenological stages, did not change too much from 89 to 131 dap, when showed small variations. Due to its low mobility, Mn presented a continuous leaf concentration increase over the time. Silva et al. (2002) also observed a continuous increase of the leaf Mn 
concentration along mango's growing season at São Francisco Valley. In the flowering time (P1), the leaf B and Cu concentrations were lower, and the $\mathrm{Fe}, \mathrm{Mn}$ and $\mathrm{Zn}$ concentrations were higher than those reported by Natale (1997a) (20-25, 20-40, 60-90, 40-80, and $25-35 \mathrm{~g} \mathrm{~kg}^{-1}$, respectively). The leaf Mn concentration was lower than that reported by Ogata et al. (1979) $\left(26 \mathrm{~g} \mathrm{~kg}^{-1}\right)$ by the end of harvesting. Malavolta et al. (1997) showed higher levels $\left(\mathrm{g} \mathrm{kg}^{-1}\right)$ of Fe (144-162) and $\mathrm{Mn}$ (202-398), and similar levels of $\mathrm{Zn}$ (28-32) only in the flowering time, and $\mathrm{Cu}(10-16)$, from 75 to 131 dap.

Fruit $\mathrm{K}$ and $\mathrm{N}$ concentrations were the highest of all nutrients found in the fruit development and harvest, and they presented a smooth decreasing along the growing season. In P2, all fruit macronutrient concentrations decreased, and $\mathrm{Ca}$ had the sharpest one. In $\mathrm{P} 3$, the variations were small, being ascendant for $\mathrm{S}$ and $\mathrm{P}$, and descendant for $\mathrm{Ca}$ and $\mathrm{Mg}$. Also, all macronutrients decreased at the end of P4 (Table 2). In general, there is an evident decrease of the nutrient levels in dry matter with the plant ontogeny (Marschner, 1995). Brasil Sobrinho et al. (1961), Hiroce et al. (1977) and Natale et al. (1994) observed lower $\mathrm{K}\left(3.13,0.73\right.$, and $1.5 \mathrm{~g} \mathrm{~kg}^{-1}$, respectively) and $\mathrm{N}(2.04,1.31$, and $1.18 \mathrm{~g} \mathrm{~kg}^{-1}$, respectively) concentrations in guava fruits, while $\mathrm{Ca}$ value herein reported were higher than in Brasil Sobrinho et al. (1961), Hiroce et al. (1977), and Natale et al. (1994) (0.02, 0.08 and $0.09 \mathrm{~g} \mathrm{~kg}^{-1}$, respectively). Among the micronutrients, Fe, $\mathrm{Mn}$, and $\mathrm{Zn}$ concentrations were the highest in the fruit development and harvesting. Their levels presented higher variations than fruit $\mathrm{Cu}$ and $\mathrm{B}$ levels over the time. In the harvesting time, all micronutrient values were higher than those reported by Natale et al. (1994). An average production of 623 guava fruits per plant was recorded, with an average fruit weight of $116 \mathrm{~g}$, and a yield of $24.097 \mathrm{~kg} \mathrm{ha}^{-1}$. The common guava production in the

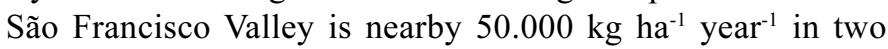
harvests (Gonzaga Neto, 2001). Based on the nutrient concentration on ripe fruits at 166, 173, 180 and 187 dap (harvesting time, Table 2), the amount of macronutrient (g) and micronutrient $(\mathrm{mg})$ removed per plant was: $92.0(\mathrm{~N}), 14.6(\mathrm{P}), 137.2$ (K), 5.0 (Ca), 6.0 (Mg), 16.7 (S), 81.6(Cu), 179.0 (Fe), 104.3 (Mn), 82.0 (B), and $113.3(\mathrm{Zn})$. Some values (N, Mg, Fe, Mn) are within the value range reported by Haag et al. (1993) (90.4-187.2 g plant ${ }^{1}, 5.6-18.7$ g plant $^{-1}, 121.2-588.8$ mg plant $^{-1}$ and 83.9-124.8 mg plant ${ }^{1}$, respectively).

In the pruning of the next growing season, the dry matter amount obtained was $26.7 \pm 0.4 \mathrm{~kg} \mathrm{plant}^{-1}$, which $53,17,17$ and $13 \%$ were distributed in the leaves, non marketable fruits, thicker twigs, and thinner twigs, respectively. The most removed macro and micronutrients by pruning were, respectively, $\mathrm{K}>\mathrm{N}>\mathrm{Ca}>$ $\mathrm{Mg}>\mathrm{S}>\mathrm{P}$, and $\mathrm{Fe}>\mathrm{Mn}>\mathrm{B}>\mathrm{Zn}>\mathrm{Cu}$ (Table 3), while Natale (1997b) reported the sequence $\mathrm{Ca}>\mathrm{N}>\mathrm{K}>\mathrm{Mg}>\mathrm{S}>\mathrm{P}$, and $\mathrm{Mn}$ $>\mathrm{Fe}>\mathrm{Cu}>\mathrm{B}>\mathrm{Zn}$.

In the pruned material, the higher $\mathrm{N}, \mathrm{P}$, and $\mathrm{K}$ contents were found in leaves and fruits, while higher $\mathrm{Ca}, \mathrm{Mg}, \mathrm{S}$ and $\mathrm{Mn}$ were determined in leaves and thinner twigs. The fruit Fe, leaf B, and thinner twigs $\mathrm{Zn}$ contents were clearly higher than in other aerial parts of the plant, while $\mathrm{S}$ and $\mathrm{Cu}$ contents were distributed on a relative homogeneous way in the aerial parts of the guava tree. Also, all nutrient contents in thinner twigs were higher than those in thicker twigs (Table 3).

The nutrient concentrations and contents reported herein showed some discrepancies from others results obtained in other Brazilian regions where guava has been cropped under different soil, climate and cultural practices (i.e., irrigation). This assessment should be taken as a first approach, but further detailed studies on mineral nutrition of irrigated guava must be carried out for the cropping system adopted in the São Francisco Valley.

TABLE 1 - Nutrient concentrations in the guava leaf based on days after pruning (dap) and phenological stages (ps).

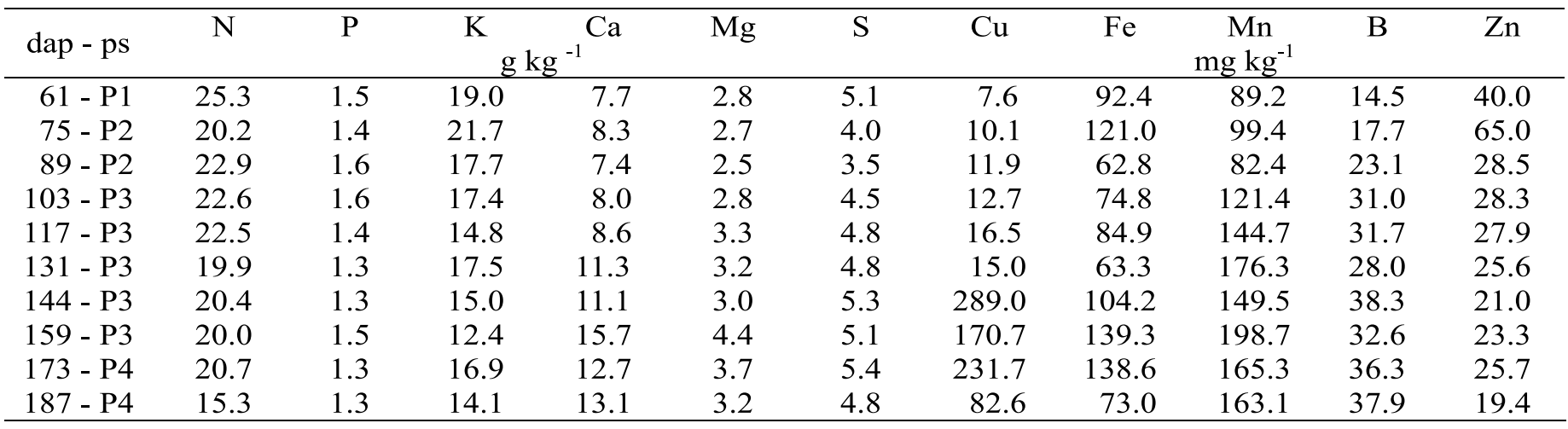


ASSESSMENT ON NUTRIENT LEVELS IN THE AERIAL BIOMASS OF IRRIGATED GUAVA IN SÃOFRANCISCO...708

TABLE 2 - Nutrient concentrations in the guava fruits based on days after pruning (dap) and phenological stages (ps).

\begin{tabular}{|c|c|c|c|c|c|c|c|c|c|c|c|}
\hline dap - ps & $\mathrm{N}$ & $\mathrm{P}$ & $\mathrm{K}$ & $\mathrm{Ca}$ & $\mathrm{Mg}$ & $\mathrm{S}$ & $\mathrm{Cu}$ & $\mathrm{Fe}$ & $\begin{array}{c}\mathrm{Mn} \\
\mathrm{mg} \mathrm{kg}^{-1}\end{array}$ & B & $\mathrm{Zn}$ \\
\hline $82-\mathrm{P} 2$ & 18.9 & 1.9 & 24.8 & 3.7 & 2.0 & 2.7 & 9.5 & 35.0 & 82.8 & 12.8 & 28.2 \\
\hline $89-\mathrm{P} 2$ & 15.4 & 1.8 & 24.2 & 3.5 & 1.9 & 2.5 & 12.0 & 79.7 & 70.0 & 12.8 & 36.0 \\
\hline $96-\mathrm{P} 2$ & 16.0 & 1.6 & 22.5 & 3.3 & 1.7 & 2.3 & 8.3 & 62.3 & 53.2 & 14.3 & 24.6 \\
\hline $102-\mathrm{P} 2$ & 14.2 & 1.5 & 20.1 & 1.5 & 1.1 & 2.1 & 8.2 & 38.1 & 28.8 & 13.1 & 19.8 \\
\hline $110-\mathrm{P} 3$ & 13.9 & 1.5 & 20.2 & 1.3 & 1.0 & 2.1 & 7.0 & 18.4 & 20.2 & 9.0 & 12.2 \\
\hline $117-\mathrm{P} 3$ & 13.9 & 1.5 & 19.2 & 1.0 & 1.0 & 2.2 & 6.1 & 17.9 & 22.5 & 10.8 & 15.1 \\
\hline $124-\mathrm{P} 3$ & 13.6 & 1.5 & 20.2 & 1.1 & 1.0 & 2.4 & 6.6 & 21.0 & 17.8 & 10.0 & 15.1 \\
\hline $131-\mathrm{P} 3$ & 15.1 & 1.7 & 20.6 & 0.9 & 1.0 & 2.4 & 7.8 & 19.6 & 19.1 & 10.6 & 15.6 \\
\hline $138-\mathrm{P} 3$ & 14.5 & 2.0 & 21.1 & 0.9 & 1.0 & 2.4 & 7.6 & 25.6 & 21.1 & 10.9 & 16.1 \\
\hline $152-\mathrm{P} 3$ & 13.6 & 2.0 & 19.5 & 0.7 & 0.9 & 2.6 & 9.1 & 33.0 & 14.5 & 11.6 & 17.3 \\
\hline $166-\mathrm{P} 4$ & 14.5 & 1.9 & 19.5 & 0.7 & 0.9 & 2.6 & 10.6 & 29.2 & 14.6 & 12.1 & 14.2 \\
\hline 173 - P4 & 12.8 & 1.9 & 18.8 & 0.7 & 0.8 & 2.3 & 10.0 & 25.0 & 14.3 & 10.9 & 15.0 \\
\hline $180-\mathrm{P} 4$ & 8.4 & 1.6 & 14.0 & 0.5 & 0.6 & 1.8 & 9.9 & 15.1 & 9.8 & 8.4 & 15.4 \\
\hline $187-\mathrm{P} 4$ & 8.4 & 1.6 & 13.5 & 0.5 & 0.6 & 1.3 & 8.6 & 16.5 & 11.3 & 7.9 & 9.7 \\
\hline
\end{tabular}

TABLE 3 - Nutrient content removed by pruning from different aerial parts of irrigated guava trees and its percentual distribution. Average from 2 plants.

\begin{tabular}{|c|c|c|c|c|c|c|}
\hline aerial parts & \multicolumn{6}{|c|}{ g plant $^{-1}(\%)$} \\
\hline $\begin{array}{l}\text { thicker } \\
\text { twigs }\end{array}$ & $\begin{array}{c}20.1 \pm 2.2 \\
(13)\end{array}$ & $\begin{array}{l}2.1 \pm 0.2 \\
(15)\end{array}$ & $\begin{array}{l}27.9 \pm 3.4 \\
(12)\end{array}$ & $\begin{array}{c}14.4 \pm 1.8 \\
(17)\end{array}$ & $\begin{array}{c}3.4 \pm 0.4 \\
(14)\end{array}$ & $\begin{array}{c}3.8 \pm 1.4 \\
(15)\end{array}$ \\
\hline $\begin{array}{l}\text { thinner } \\
\text { twigs }\end{array}$ & $\begin{array}{l}27.3 \pm 1.7 \\
\quad(18)\end{array}$ & $\begin{array}{l}2.7 \pm 0.6 \\
(19)\end{array}$ & $\begin{array}{l}49.0 \pm 4.2 \\
\quad(21)\end{array}$ & $\begin{array}{c}34.6 \pm 0.8 \\
\quad(41)\end{array}$ & $\begin{array}{c}7.5 \pm 0.4 \\
(31)\end{array}$ & $\begin{array}{c}6.6 \pm 1.3 \\
(27)\end{array}$ \\
\hline leaves & $\begin{array}{c}56.6 \pm 3.3 \\
(37)\end{array}$ & $\begin{array}{c}3.8 \pm 1.6 \\
(30)\end{array}$ & $\begin{array}{l}66.4 \pm 4.1 \\
\quad(29)\end{array}$ & $\begin{array}{c}33.1 \pm 1.3 \\
\quad(39)\end{array}$ & $\begin{array}{c}9.8 \pm 0.2 \\
(40)\end{array}$ & $\begin{array}{c}8.5 \pm 2.2 \\
(35)\end{array}$ \\
\hline fruits* & $\begin{array}{l}49.0 \pm 2.6 \\
(32)\end{array}$ & $\begin{array}{l}5.3 \pm 0.5 \\
(37)\end{array}$ & $\begin{array}{l}88.5 \pm 4.3 \\
\quad(38)\end{array}$ & $\begin{array}{l}2.7 \pm 0.3 \\
(3)\end{array}$ & $\begin{array}{l}3.8 \pm 0.2 \\
\quad(15)\end{array}$ & $\begin{array}{l}5.5 \pm 0.9 \\
\quad(23)\end{array}$ \\
\hline \multirow[t]{2}{*}{ total } & $153.3 \pm 0.6$ & $14.0 \pm 1.8$ & $231.9 \pm 3.1$ & $84.7 \pm 4.1$ & $24.5 \pm 0.8$ & $24.3 \pm 1.3$ \\
\hline & $\mathrm{Cu}$ & $\mathrm{Fe}$ & \multicolumn{2}{|c|}{ mg plant $^{-1}(\%)$} & 3 & $\mathrm{Zn}$ \\
\hline $\begin{array}{l}\text { thicker } \\
\text { twigs }\end{array}$ & $\begin{array}{l}44.7 \pm 2.5 \\
\quad(19)\end{array}$ & $\begin{array}{c}231.9 \pm 99.0 \\
(16)\end{array}$ & \multicolumn{2}{|c|}{$\begin{array}{l}190.8 \pm 14.4 \\
(14)\end{array}$} & $\begin{array}{l}49.9 \pm 3.8 \\
(10)\end{array}$ & $\begin{array}{l}51.7 \pm 1.6 \\
(19)\end{array}$ \\
\hline thinner twigs & $\begin{array}{l}79.9 \pm 7.1 \\
(35)\end{array}$ & $\begin{array}{c}273.2 \pm 25.9 \\
\text { (19) }\end{array}$ & \multicolumn{2}{|c|}{$\begin{array}{c}542.2 \pm 22.5 \\
(41)\end{array}$} & $\begin{array}{l}68.4 \pm 1.3 \\
(14)\end{array}$ & $\begin{array}{c}105.1 \pm 12.7 \\
(39)\end{array}$ \\
\hline leaves & $\begin{array}{l}58.6 \pm 23.7 \\
\quad(26)\end{array}$ & $\begin{array}{c}334.7 \pm 51.7 \\
\quad(23)\end{array}$ & \multicolumn{2}{|c|}{$\begin{array}{c}542.0 \pm 12.0 \\
(40)\end{array}$} & $\begin{array}{c}333.6 \pm 27.4 \\
(68)\end{array}$ & $\begin{array}{c}49.3 \pm 1.0 \\
(19)\end{array}$ \\
\hline fruits* & $\begin{array}{l}44.6 \pm 3.9 \\
\quad(20)\end{array}$ & $\begin{array}{c}590.9 \pm 298.9 \\
(41)\end{array}$ & \multicolumn{2}{|c|}{$\begin{array}{c}63.7 \pm 4.1 \\
(5)\end{array}$} & $\begin{array}{c}42.0 \pm 5.2 \\
(9)\end{array}$ & $\begin{array}{c}60.2 \pm 2.9 \\
(23)\end{array}$ \\
\hline total & $228.4 \pm 23.3$ & $1432.4 \pm 315.1$ & \multicolumn{2}{|c|}{$1337.1 \pm 9.0$} & $493.9 \pm 43.7$ & $264.6 \pm 18.2$ \\
\hline
\end{tabular}




\section{REFERENCES}

BRASIL SOBRINHO, M.O.C.; MELLO, F.A.F.; HAAG, H.P.; LEME JR., J. A composição química da goiabeira (Psidium guajava L.). Anais da Escola Superior de Agricultura "Luiz de Queiroz", Piracicaba, v.18, p.183-192, 1961.

CHADHA, K. L.; ARORA, J. S.; RAVEL, P.; SHIKHMANY, S. D. Variation in the mineral composition of the leaves of guava mineral (Psidium guajava L.) as affected by leaf position, season and sample size. Indian Journal of Agricultural Science,Índia Nova Deli, v.43, n.6, p.555-561, 1973.

CHADHA, K. L.; SAMRA, J. S.; THAKUR, R. S. Standardization of leaf-sampling technique for mineral composition of leaves of mango cultivar Chausa. Scientia Horticulturae, Amsterdan, v.13, p.323-329, 1980 .

EMBRAPA. Centro Nacional de Pesquisa de Solos. Manual de métodos de análise de solo. 2 ed. Rio de Janeiro: Embrapa- SPI, 1997.212p.

GONZAGA NETO, L.; SILVA, D. J.; PEREIRA, J.R. Recomendações de calcário e fertilizantes. In: CAVALCANTI, F.J.A. (Ed.) Recomendações de adubação para o estado de Pernambuco ( $2^{a}$ aproximação). Recife: IPA, 1998. p.147

GONZAGA NETO, L. Goiaba: produção aspectos técnicos. Brasília: Embrapa Informação Tecnológica, 2001. 72p. il. (Frutas do Brasil; 17).

HAAG, H.P.; MONTEIRO, F.A.; WAKAKURI, P.Y. Frutos de goiaba (Psidium guayava L.): desenvolvimento e extração de nutrientes. Scientia Agricola, Piracicaba, v.50, n.3, p.413-418, 1993.

HIROCE, R.; CARVALHO, A. M.; BATAGLIA, O. C.; FURLANI, P. R.; FURLANI, A. M. C.; SANTOS, R. R.; GALO, J. R. Composição mineral de frutas tropicais na colheita. Bragantia, Campinas, v.36, p.155-164, 1977.

KHANDUJA, S.D.; GARG, V.K. Nutritional status of guava (Psidium guajava L.) trees in North India. Journal of Horticultural Science, Ashford, v.55, n.4, p.433-435, 1980.

MALAVOLTA, E.; VITTI, G.C., OLIVEIRA, S.A. Avaliação do estado nutricional das plantas: princípios e aplicações. 2.ed. Piracicaba: Potafos, 1997.319p.

MARSCHNER, H. Mineral nutrition of higher plants. 2. ed. Cambridge: Academic Press, 1995. 690p.
MEDINA, J.C.; Goiaba- cultura. In: ITAL. Goiaba: cultura, matériaprima, processamento e aspectos econômicos. 2.ed. Campinas: ITAL; Instituto Campineiro de Ensino Agrícola, 1988. Cap. 1, p. 1-120. (Frutas Tropicais, 6).

NATALE, W. Diagnose da nutrição nitrogenada e potássica em duas cultivares de goiabeira (Psidium guajava L.), durante três anos. Piracicaba, 1993. 150p. Tese (Doutorado) - Escola Superior de Agricultura “Luiz de Queiroz”, Universidade de São Paulo.

NATALE, W.; COUTINHO, E.L.M.; BOARETTO,A.E.; CORTEZ, G.E.P. Extração de nutrientes por frutos de goiabeira (Psidium guajava L.). Científica, Jaboticabal, v.22, n.2, p.249-253, 1994.

NATALE, W. Nutrição mineral e adubação de frutíferas: goiabeira. In: SIMPÓSIO BRASILEIRO SOBRE A CULTURA DA GOIABEIRA, 1., Jaboticabal, 1997. Anais. Jaboticabal: UNESPFCAV, FUNEP, GOIABRAS, 1997a. p.63-92.

NATALE W. Extração de nutrientes pela poda. In: SIMPÓSIO BRASILEIRO SOBRE A CULTURA DA GOIABEIRA, 1., Jaboticabal, 1997. Anais. Jaboticabal: UNESP- FCAV, FUNEP, GOIABRAS, 1997b.p.169.

OGATA, T.; SANTOS, M. G. F. M.; ABRAHÃO, E.; SOUZA, M. de. Influência da cultivar, posição e número de frutos do ramo no teor de nutrientes da folha de goiabeira (Psidium guajava L.). In: CONGRESSO BRASILEIRO DE FRUTICULTURA, 5., Pelotas, 1979. Anais. Pelotas: SBF, 1979. p.198-204.

QUEIROZ, E. F.; KLIEMANN, H. J.; VIEIRA, A.; RODRIGUES, A. P. M.; GUILHERME, M. R. Nutrição mineral e adubação da goiabeira (Psidium guajava L.). In: HAAG, H. P. (Ed.) Nutrição mineral e adubação de fruteiras tropicais no Brasil. Campinas: Fundação Cargill, 1986. p.165-187.

RAIJ, B. VAN; CANTARELLA, H.; QUAGGIO, J. A.; FURLANI, A. M. C. Recomendações de adubação e calagem para o Estado de São Paulo. Campinas: Instituto Agronômico, Fundação IAC, 1997.285p.

RODRIGUEZ, S. J. Variation in chemical composition of guava leaves (Psidium guajava $\mathrm{L}$.) as affect by position in the terminais. Journal of Agriculture of the University of Puerto Rico, Rio Piedras, v.51, p.252-259, 1967.

SILVA, D.J.; QUAGGIO, J.A.; PINTO, P.A.C.; PINTO, A.C.Q.; MAGALHÃES, A.F.J. Nutrição e adubação In: GENÚ, P.J.C.; PINTO, A.C.Q. (Ed.) A cultura da mangueira. Brasília: Embrapa Informação Tecnológica, 2002. cap. 10, p.191-221. 